\title{
User Resistance in IT: A literature review
}

\author{
Mahmood $\mathrm{Ali}^{{ }^{*}}$, Li Zhou${ }^{2}$, Lloyd Miller $^{2}$, Petros Ieromonachou ${ }^{2}$ \\ ${ }^{1}$ College of Business Administration, University of Business and Technology, Jeddah 21361, \\ KSA \\ ${ }^{2}$ Faculty of Business, University of Greenwich, London SE10 9LS, UK
}

\begin{abstract}
User resistance is a complex phenomenon long viewed as a major constraint in successful information technology implementation. User resistance, which can vary between passive and active, could be a source of guidance towards reducing problems associated with organisational change. However, rather than embracing user resistance and seeing it as a learning opportunity and a tool for managing current and future difficulties around user resistance, organisations fear it. There exist a wide literature on user resistance spanning decades; focusing separately on user resistance, and various related factors. However, there is no comprehensive overview of the research work published. This study presents a comprehensive literature review to gain a better understanding of the contents of the current user resistance literature. Based the findings from the literature review, areas of concern and the impact of user resistance on the development of new information technology are identified and how to overcome the resistance is suggested.
\end{abstract}

Keywords: User resistance, information technology, literature review, overcome resistance, strategy. 


\section{Introduction}

User resistance issues are of primary focus in information technology (IT) related projects. In today’s business environment, technology is playing a critical role in improving organisational effectiveness and is being implemented extensively, understanding user resistance has gained considerable attention in the literature (Dickson and Simmons, 1970; Keen, 1981). Goodhue and Thompson (1995) argue that not understanding user resistance may lead to less productivity, which in turn can create serious problems for businesses. Hill (2003, p.1) asserts that user resistance must be understood since it has been found to be "at the root of many enterprise software project failures.” Gravenhorst and Veld (2004) suggest that change and resistance go hand in hand; accordingly, change suggests resistance, and resistance imply change. For such reasons, Doppler (2004) advises against ignoring the causes of user resistance, and suggests that recognising and taking appropriate action will reduce enduring problems.

The user resistance literature covers a wide range of area such as various reasons, outcomes, and list of factors relating to user resistance. Markus (1983) states that IT development is a political beast as well as a technological animal where resistance is not a problem to be solved, but more a useful clue as to what went wrong. King and Anderson (1995, p. 168) describe user resistance as a “complex kaleidoscope of interrelated factors.” While Jiang et al. (2000) conclude that user resistance problems are wide and pervasive and no single feature can describe the phenomenon entirely. There are several examples of user resistance in the industry such as 'user resistance extended the duration of a US\$6.9 billion defence intranet project by eightfold (Verton, 2002); underutilisation of new implemented enterprise system at a soft drink maker (Barker and Frolick, 2003); a company was forced to redevelop customer relationship management system when employees refused to use the original version (Kim and Pan, 2006); and research fieldwork 
undertook in China in July 2015 by the authors witnessed that in logistics companies majority of drivers refused to use transport monitoring system because they can be tracked and felt being watched by management all the time'. Therefore, in an effort to contribute to better understanding of the IT resistance, this study provides a survey of the published literature on user resistance, its causes, theories of resistance, and looks at strategies to overcome resistance, and other issues relating to user resistance.

The purpose of this study is threefold. Firstly, to overview research in the area of user resistance.

Secondly, to overview the causes of user resistance. Finally, based on the findings from the study, we suggest the strategies to overcome user resistance, and offer recommendations for future research in this area.

The paper is organised as follows: Section 2 describes the definitions of user resistance in the literature. This is followed by a general discussion on user resistance in section 3. Section 4 describes the methodology we adopt in the literature review. The theories of user resistance are discussed in section 5 , followed by an examination of user resistance in section 6 . In Section 7, the strategies of how to overcome resistance are reviewed. Finally, section 8 concludes and provides future research direction.

\section{Definition of User Resistance}

In the management literature, resistance is defined as a multifaceted phenomenon which brings forth unanticipated delays, costs and instabilities into the process of strategic change (Ansoff, 1988, p. 207). It is any conduct that serves to maintain the status quo in the face of pressure to change it (Zaltman and Duncan, 1977, p. 63). 
Resistance to change is the intentional acts or commission that defy the wishes of others (Ashforth and Mael, 1998; Newman, 1989). Kim and Kankanhalli (2009) define user resistance as opposition of a user to changes associated with a new IT implementation. Klaus and Blanton (2010) classify user resistance as the behavioural expression of a user's opposition to system implementation and during implementation. User resistance is therefore a reaction to present on-going situations, perceived as a negative or stressful feeling (Ang and Parvi, 1994; Marakas and Hornick, 1996). It appears when users perceive changes as 'unfair' in regards to their or group workloads (Joshi, 1991).

In the IT sector, user resistance is defined as behaviour intended to prevent the implementation and use of new systems, or to prevent system designers from achieving their objectives (Markus, 1993). Such resistance to a proposed change is an adverse reaction, which may manifest itself in a visible and overt fashion (such as sabotage or direct opposition), or in a less obvious and covert action (such as inertia) to stall and ultimately kill a project.

\section{Framework of the literature review}

The introduction of new technology frequently involves varying levels of change to business processes and how employees carry out their daily job functions. This change can be as minor as a simple modification in the user interface, or installing a new application. Equally, it can be as complicated as implementing a complete enterprise system, such as SAP, Oracle, Lawson, MS Dynamics, etc. which requires a complete business transformation. Users react differently to these changes. Their responses can range from partial to complete acceptance of the changes, to absolute rejection of the new system, which in many cases may lead to project failure (Nov and Ye, 2008). In a summary of 13 recent studies by Jain (2004), in using IT as a tool for reform or change, at least six of the failures are attributed to employee's resistance to change. 
Kling (1980) views resistance from three perspectives: people oriented, system oriented, and interaction theories. People oriented theory suggests that resistance to a system is created by factors internal to users as individuals or groups (Jiang et al. 2000), similar to Munford and Bank (1967). This is consistent with Sacks (1993) who explains that a user's individual beliefs, values and understanding contribute to individual's attitudes to new systems. The system oriented approach posits that resistance is induced externally by factors inherent in the design and introduction of a new system. Finally, interaction theory analyse the interaction between the user and the system. It is based on the premises that systems acquire different political and social meaning in different settings, whilst different users perceive the effect of the same system differently (Joshi, 1991; Kling, 1980). Given these three perspectives are commonly accepted, this paper adopts it as the framework of the literature review.

\section{Research Methodology}

In this section the research methodology used for conducting the literature review is presented.

Due to the volume of literature under study, the research methodology is divided into three phases (see Figure 1). The first phase involves a search of the inventory of research journals to locate studies on IT systems and implementation using the Swetwise, ProQuest, EBSCO, Emerald, SceinceDirect, Wiley Interscience, and ACM Digital library databases (see Table 1). The keywords used in the database searches are: implementations, IT and user resistance. The selected journals (Table 1) represent the group of major scholarly journals in the area of user resistance and are extensively cited. In addition, they represent wide spectrum of the research area (such as human behaviour, communication, decision sciences, human and computer interaction, psychology, change management, organisation science and strategic management) besides field of IT, thus enriching this literature review. 
The second phase involves the identification and review of papers exclusively on user resistance. As a part of the selection process, the research papers focus on abstracts, keywords, research findings, etc., which enables us to identify and select the papers only on user resistance.

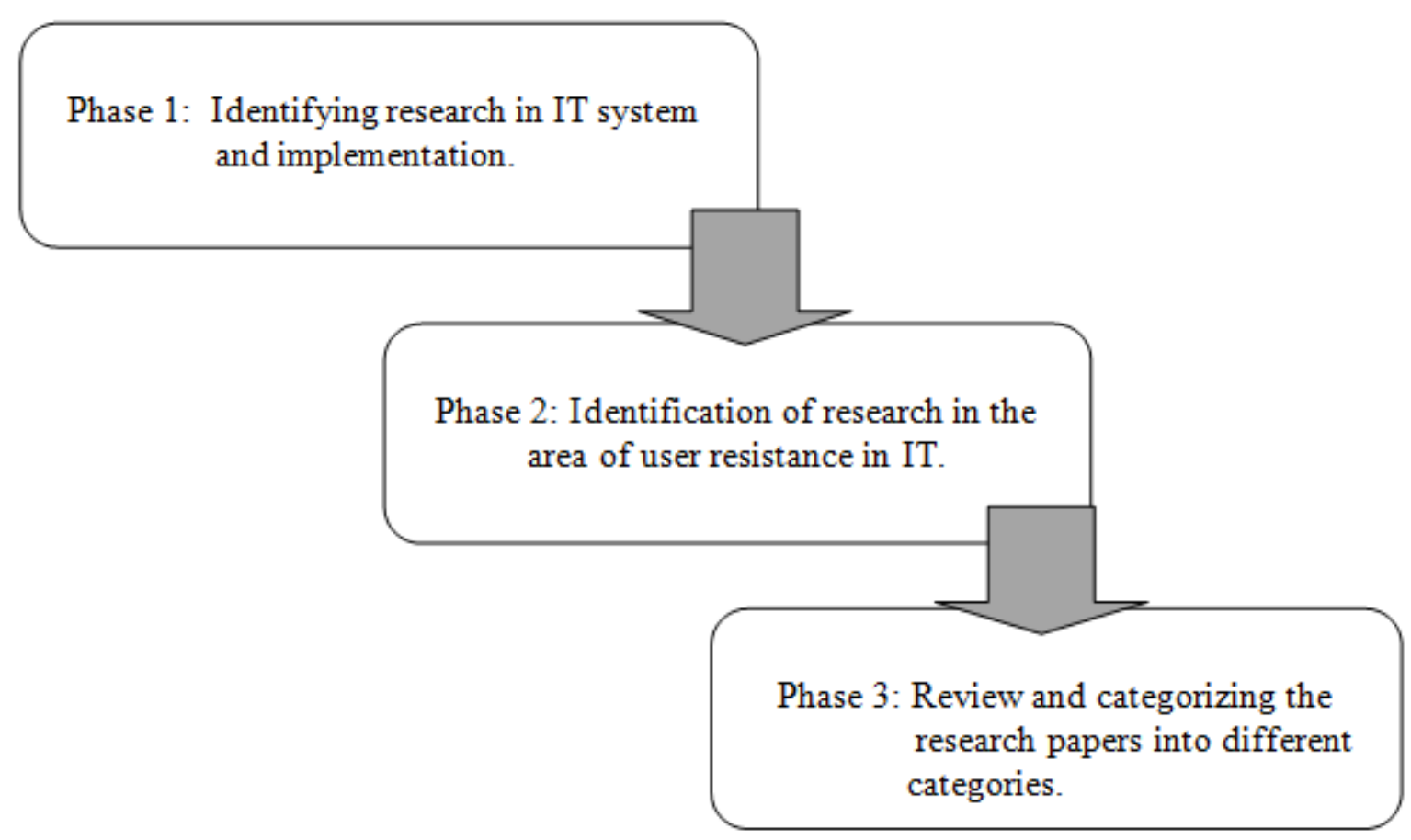

Figure 1 Research framework

In the final phase, the papers identified and reviewed are categorised. For this study, the classification proposed by Esteves and Bohorquez (2007) who reviewed the literature based on ERP lifecycle framework is adopted.

Table 1 Bibliographical database included

Behaviour and Information Technology

Business Process Management 


\section{Communications of ACM}

Database for Advances in Information Systems

\section{Decision Sciences}

European Journal of Information Systems

Harvard Business Review

Information \& Management

Information System Management

Information System Research

Information Systems Journal

International Journal of Human-Computer Interaction

International Journal of Information Management

Journal of Business and Psychology

Journal of Computer Information Systems

Journal of Enterprise Information Management

Journal of Information Technology Case and Application Research

Journal of Information Technology Management

Journal of Management Information System

Journal of Organisational Change Management

Journal of System Management 
Management Informatics

Management Science

MIS Quarterly

Organisation Science

Strategic Management Journal

The Computer Journal

In an attempt to focus and understand user resistance, we classify the literature into different sub categories - theories of resistance, followed by examining user resistance classified as system oriented, people oriented, and interaction oriented resistance. To gain in-depth knowledge, content analysis is adopted to enhance classification and provide rigour process (Cumbie, et.al., 2005). For the content analysis, we focus on the abstracts of the papers to gain an understanding of the research topic. This results in better categorisation and creates a positive impact on the analysis.

\section{Major Sources of Resistance}

Val and Fuentes (2003) extend the work of Rumlet (1995) by dividing sources of user resistance into five groups relating to formulation and implementation. The five groups are explained in the following sections. The first three groups deal with sources of formulation, and the last two groups deal with implementation.

i. Distorted perception: Val and Fuentes (2003) termed the first group, distorted perception, interpretation barriers and vague strategic priorities. It includes;

- $\quad$ Myopia, or inability of the company to look into the future with clarity (Barr et al., 1992;

Kruger, 1996; Rumlet, 1995). 
- $\quad$ Denial or refusal to accept any information that is not expected or desired (Barr et al., 1992; Rumlet, 1995).

- $\quad$ Perpetuation of ideas, the tendency to go on with present thoughts although the situation has changed (Barr et al., 1992; Kruger, 1996; Rumlet, 1995; Zeffane, 1996).

ii. Low motivation for change: This includes:

- $\quad$ Direct cost of change (Rumlet, 1995).

- $\quad$ Cannibalisation costs, changes which bring success to the project but may bring losses to others, so it requires some sort of sacrifice (Rumlet, 1995).

- $\quad$ Past failures

- $\quad$ Different interest level among employees and management (Waddell and Sohal, 1998).

iii. Lack of creative response: This includes the main reasons for diminished creativeness in the search for appropriate change strategies.

- $\quad$ Fast and complex environmental changes, which do not allow a proper situation analysis (Ansoff, 1990; Rumlet, 1995).

- $\quad$ Reactive mind set, resignation, or tendency to believe that obstacles are inevitable (Rumlet, 1995).

- $\quad$ Inadequate strategic vision or lack of clear commitment of top management to change (Waddell and Sohal, 1998; Rumlet, 1995).

iv. Political and cultural deadlock: This results from following;

- When there is a negative relationship between implementation climate and change values and organisational values, resistance and opposition to change will result (Klein and Sorra, 1996).

- $\quad$ Departmental politics (Beer and Eisentat, 1996; Rumlet, 1995). 
- Incommensurable belief, or strong and definitive disagreement among group members (Klein and Sorra, 1996; Rumlet, 1995; Zeffane, 1996).

- $\quad$ Deep rooted values and emotional loyalty (Kruger, 1996; Nemeth, 1997; Strebel, 1994).

v. Other sources of resistance: Other sources of resistance include:

- $\quad$ Leadership inaction, sometime due to fear of uncertainty or changing the status quo (Beer and Eisentat, 1996; Rumlet, 1995; Kruger, 1996; Rumlet, 1995; Maurer, 1996).

- $\quad$ Embedded routines (Hannan and Freeman, 1984; Rumlet, 1995; Starbuck, Greve and Hedgeberg, 1978).

- $\quad$ Collective action problems (Rumlet, 1995).

- $\quad$ Lack of necessary capabilities to implement change (Rumlet, 1995).

- $\quad$ Cynicism (Maurer, 1996; Reichers, Wanous and Austin, 1997).

In addition, among the measures to evaluate expected resistance, Joshi (1991) proposes an equity implementation model (EIM). It suggests that users evaluate change relating to new IT implementation is based on net equity. The net equity is estimated as the differences between changes in outcomes, i.e. increase or decrease in outcome, and changes in input, i.e. increase or decrease in input. If the net equity is perceived, users will be resistant to changes. Similarly, Kim and Kankanhalli (2009) propose a cost-benefit analysis of change where switching costs play a central role in increasing user resistance. Switching costs also mediates the relationship between several factors, such as user's opinion, user resistance and so on. Kim (2011) adds that uncertainty and sunk costs directly increase user resistance, while transition and loss costs indirectly increase user resistance by reducing the perceived value of switching.

Table 2 Summary of the causes of resistance 


\begin{tabular}{|c|c|}
\hline Change of status quo & Ginzberg and Reilley (1957) \\
\hline Uncertainty & $\begin{array}{l}\text { Hirschheim and Newman (1988), Sander (1974), Jiang et } \\
\text { al., (2000), Krovi (1993) }\end{array}$ \\
\hline Lack of involvement in the change & Evelamd (1977), Hirschheim and Newman (1988) \\
\hline Redistribution of resources & Hirschheim and Newman (1988) \\
\hline Organisational mismatch & $\begin{array}{l}\text { Hirschheim and Newman (1988), Markus and Robey, } \\
\text { (1983) }\end{array}$ \\
\hline Lack of top management support & $\begin{array}{l}\text { Krovi (1993), Hirschheim and Newman (1988), Martinko } \\
\text { et al. (1996), Waddell and Sohal (1998), Rumlet (1995) }\end{array}$ \\
\hline Reliability issues & $\begin{array}{l}\text { Hirschheim and Newman (1988), Venkatesh and Bala, } \\
\text { (2008) }\end{array}$ \\
\hline $\begin{array}{l}\text { Lack of interaction between system } \\
\text { developers and user }\end{array}$ & Chreim (2006) \\
\hline Lack of training for the new system & Lucas (1973) \\
\hline $\begin{array}{l}\text { Lack of education about the system } \\
\text { being introduced }\end{array}$ & Heany (1972) \\
\hline Cognitive style & Huber (1983), Mason (1973), Zmud (1979) \\
\hline Changes in job contents & DeSanctis and Courtney (1983) \\
\hline Rigidity, perpetuation of ideas & $\begin{array}{l}\text { Marakas and Hornick (1996), Barr et al. (1992), Kruger ( } \\
\text { 1996), Rumlet (1995), Zeffane (1996) }\end{array}$ \\
\hline Net inequity & Joshi (1991, 2005), Keen (1981), Markus (1983) \\
\hline Role conflict and role ambiguity & Joshi (1989) \\
\hline Lack of communication & $\begin{array}{l}\text { Wanberg and Banas (2000), Lewis (2006), Oreg (2006), } \\
\text { Nah et al. (2004). }\end{array}$ \\
\hline
\end{tabular}




\begin{tabular}{|l|l|}
\hline Subjective norms & $\begin{array}{l}\text { Venkatesh et al. (2003), Schepher and Wetzels (2007), } \\
\text { Thompson et al. (1991) }\end{array}$ \\
\hline costs, suck cost & Kim and Kankanhalli (2009), Rumlet (1995), Kim (2011) \\
\hline Myopia & Barr et al. (1992), Kruger (1996), Rumlet (1995) \\
\hline Denial & Barr et al. (1992), Rumlet (1995) \\
\hline Variation in interest level & Waddell and Sohal (1998) \\
\hline $\begin{array}{l}\text { Fast and complex change } \\
\text { environment }\end{array}$ & Ansoff (1990), Rumlet (1995) \\
\hline Reactive mind set. resignation & Rumlet (1995) \\
\hline $\begin{array}{l}\text { Negative relationship between } \\
\text { teams }\end{array}$ & Klein and Sorra (1996), Rumlet (1995) \\
\hline Departmental politics & Beer and Eisentat (1996), Rumlet (1995) \\
\hline Incommensurable belief & Klein and Sorra (1996), Rumlet (1995), Zeffane (1996) \\
\hline $\begin{array}{l}\text { Deep rooted values and emotional } \\
\text { loyalty }\end{array}$ & Kruger (1996), Nemeth (1997), Strebel (1994) \\
\hline Lack of leadership & Beer and Eisentat, 1996; Rumlet, 1995; Kruger, 1996; \\
\hline Embedded routines & Rumlet, 1995; Maurer, 1996 \\
\hline Lack of necessary capabilities & Rumlet (1995) \\
\hline Maurer (1996), Reichers et al. (1997) \\
\hline (1995)
\end{tabular}




\section{Examining User Resistance}

Nodeson et al. (2012) conclude that the effectiveness of an organisation requires a strong sense of direction, building and transforming capabilities while minimising user resistance. Research suggests that among the factors associated with IT project failures, user resistance is one of the most significant causes (Jiang et al. 2000; Meissonier and Houze, 2010). In the following sections, a review on user resistance is presented, based on the Markus (1983) classification as derived from the work of Kling (1980). The classification is based on the premise that better understanding of user resistance will lead to better implementation strategies and better outcomes for the organisations in which IT systems are installed.

\subsection{System Oriented}

The system oriented approach suggests that resistance occurs because of technology-related factors such as user interface, performance security, ease of use, and degree of centralisation which may not be as user friendly or easy to interact with as intended (Markus, 1983). Likewise, if the system reacts too slowly, crashes frequently, is unavailable at critical times, has data quality issues, or the quality of output information is not valid, it can generate negative user attitude towards new technology, which in turn can lower usability (Dickson and Wetherbe, 1985; Markus, 1983; Martinko, 1996). Similarly, after implementation, if the system is not reliable, or technical quality is unsatisfactory, users are unlikely to welcome the new system and will avoid it (Hirschheim and Newman, 1988).

Markus (1983) argues that people resist new IT systems because of their own internal factors, poor system design and interaction of specific system design features with respect to the organisational context of system use. Markus (1983) terms this political variant of interaction theory (PVIT) and explains it as group resistance in terms of the interaction between IT and the context of its use. 
The model's primary assumption is that an IT system embodies the distribution of power among the actors that it affects. The degree to which intended users feel the ease of using new system frequently determines the level of resistance (Dickson and Wetherbe, 1985). If users see the new system as being unfriendly and difficult to use, they will tend to avoid it. However, if the system improves the user's task performance or decision quality, then they are more likely to use the IT, otherwise, they may refrain from adopting to new technology (Lapointe and Rivard, 2005).

Ives and Olsen (1984) suggest that during system development, if users are not involved, then there can be a disparity between the aims of system developers or implementers and users. It is due to these reasons that system developers are mostly concerned with the technical aspects of IT systems, whilst users are mostly interested in the new technology to the extent of its impact on their jobs.

Further analysing users acceptance or rejection of new systems, Tzeng (2011) proposes that users perception of a system's value rest on their practical experience with the system. These experiencebased perceptions provide clear clues for users to decide whether to use the system or not (Carney, 2002; Venkatesh and Davis, 1996, 2000).

\subsection{People Oriented}

The people oriented approach suggests that user resistance occurs because of individual or group factors such as background, traits, attitudes and experience towards technology (Markus, 1983). Individual's level of interaction with new IT system is based on internal and external influences, which in turn directly impact the level of IT usage (Martinko, Henry and Zmud, 1996). In addition, it leads to outcome and efficacy expectancies, while the negative expectancies among them lead to user resistance. Positive expectancies and user evaluation of systems encourage user acceptance (Bukhari, 2005; Norzaidi, Chong, Salvani and Rafidah, 2008). 
Users frequently become accustomed to the system they are using for years, and do not understand the business needs of new advanced systems and therefore resist them. Sometimes, resistance is higher at group than at individual level suggesting that groups are more likely to resist any changes introduced by IT systems (Lapointe and Rivard, 2005). Markus (1983) find that group level resistance is often socio-political, whilst at the individual level it is psychological, and therefore, each scenario requires a unique strategy to minimise resistance.

People oriented factors are also related to the required skills a user must achieved to qualify for the job and the changes introduced by new technology (Markus, et al., 2000; Besson and Rowe, 2001; Jiang, et al. 2000; Krovi, 1983). Jiang et al. (2000) note that changes in job content have been shown to underpin resistance in adopting new technology. This may be overcome by incorporating training to minimise resistance. Henry (1994) proposes that special attention should be given to users to reduce their anxiety through special training programs which will give users a sense of participation and feeling of "vested interest" leading to reduction of anxiety and negative attitudes towards new IT systems.

Selander and Henfridsson (2012) defined cynicism as cognitively distanced resistance that constitute negatively towards IT implementation, and manifest a perception of seeing through the espoused goal of the implementer. Similarly, Stanley, Meyer and Topolnytsky (2005) and Gabriel (1999) identify relations between organisational change, cynicism and resistance.

Waddell and Sohal (1988) identified resistance as a function of a variety of social factors, including:

- Rational factors: resistance can occur where an employee's own rational assessment of the outcomes of a propose change differ with the outcomes envisaged by management. Such differences of opinion cast doubt in the employees' mind as to the merit or worth of the changes, 
and thus they may choose to stand in opposition or voice concern (Ansoff, 1988, p. 211; Grusky and Miller, 1970, p. 63; Kotter et al., 1986, p. 352).

- Non-rational factors: the reaction of an individual worker to a proposed change is also a function of predispositions and preferences which are not necessarily based on an economic-rational assessment of the change. These may include for instances workers who simply do not wish to move offices, prefer working near a particular friend, or are uncertain of the outcomes of implementing new technology (Judson, 1966, p. 19; Kaufman, 1971, p. 15; McNurry, 1973, p. 381; Sayles and Straus, 1960, p. 305).

- Political factors: such as favoritism or "point scoring" against those initiating the change effort (Blau, 1970, p.135, Grusky and Miller, 1970; Ansoff, 1988, p.212).

- Management factors: inappropriate or poor management styles also contribute to resistance (Judson, 1966; Lawrence, 1954).

Eveland (1977, p.4) note that user 'resistance to change is not so much resistance to changing itself; as it is to being changed by others.' This could be avoided by further establishing a line of communication during the implementation process. Pieterse, Caniels and Homan (2012) find that a successful implementation requires a good line of communication, which should be clear, explicit in definitions, assumptions, beliefs and expectations from the group of professionals involved in the project. They also stress upon the need for paying attention to the language used during process change which should be easy for user to understand.

The literatures suggest that user's response to new technology could be directly correlated with following personality factors: 
User age: is generally observed that younger users tend to be more flexible and accommodating with changes in comparison with users from other age group (Fuerst and Cheney, 1982; Lucas, 1973).

Educational level: in comparison with less educated users, higher educated users are more willing to accept and utilise new IT systems (Fuerst and Cheney, 1982).

Perceived need: there is likelihood of increased acceptance if users perceive a need for a new IT system (Dickson and Wetherbe, 1985).

Degree of expected use of IT: if users feel that IT systems will contribute to their performance and improve work productivity, they are more likely to adopt the new IT system (Zmud, 1979).

Ginzberg and Reilley (1957, p.9) conclude that resistance to change is frequently derived from user reluctance to change the status quo, as they 'prefer to stay with the work they know, rather than take on new assignment.' Samuelson and Zeckhauster (1988) propose a status quo biased theory, which explains people's preference for maintaining their current status or situation. This includes users who seek routines, have negative reactions to announcement of change with a shortterm focus and possessa rigid or dogmatic point of view.

\subsection{Interaction Oriented}

Markus (1983) suggest that interaction oriented approach is related to people resisting a new system because of interaction between characteristics related to the people and the characteristics related to the system. It is not the same as a simultaneous belief in system and people oriented theories. Central to this perspective is the notion that a system acquires different political and social meaning in different settings and that different users perceive the effect differently (Jiang et al. 2000). The interaction-oriented approach suggests that perceived social losses caused by 
interaction among people and technology, such as changing power relationship, social structure, and job structure affects resistance (Markus, 1983). Such changes accompanied by new IT implementation bring changes in resources distribution across the organisation. These changes can include departmental budgets, equipment, staff and territory, individual authority, status, role and salary (Hirschheim and Newman, 1988).

Davenport (1998) suggests that new IT systems can give more power to key users by allowing them to access real time data. However, IT systems can reduce the autonomy of employees, which in some cases lead to increase user resistance (Markus, 1983; DeSanctis and Courtney, 1983; Jiang et al. 2000; Joshi, 1991; Krovi, 1993, Lapointe and Rivard, 2005, 2007; Dickson and Wetherbe, 1985; Husain and Husain, 1984; Joshi, 1991). This may also lead to the feeling of loss of power, which is when users believe that IT involves a power shift which will undermine their power and/or position, thus resulting in resistance behaviour (Lapointe and Rivard, 2005; Kim and Kankanhalli, 2009).

Psychological contract between employees and an organisation usually influence user behaviour towards new technology. Klaus and Blanton (2010) propose twelve determinants that can affect the psychological contract and the level of user resistance. Deriving four categories from these determinants, namely individual, system, organisational and process issues, they devise a framework to analyse and develop strategies to minimise resistance and suitable relationship between the psychological contract and employees.

Meissonier, Houze and Bessiere (2012) analyse user resistance from the perspective of crosscultural frictions. Studying the ERP implementation process, they observe that lack of organisational fit, and consequently resistance resulting from cultural misfit, often leads to a failure. They find that value conflict usually arise from inconsistency between the cultural 
principles of users, and perceived underlying objectives assigned to ERP implementation. In addition, perceived value and organisational support for change reduce user resistance. Other commonly observed issues include systems not 'fitting with individuals and groups work patterns, or with the structure of the organisation' (Hirschheim and Newman, 1988; Markus and Robey, 1983).

Eckhardt, Laumer and Weitzel (2009) study the role of social influence on different workplace groups, and their intention to adopt new technology. They conclude that there is a significant impact on social influence from workplace experiences on IT adoption, such as social influence in the same department will be different for adopters and non-adopters.

It is observed that people are generally averse to uncertainty in their decision making and behaviour because of feelings of incompetence in uncertain situations, which in turn causes negative psychological reactions. It bias users toward the status quo (Kim and Kankanhalli, 2009; Brown and Venkatesh, 2005; Samuelson and Zeckhauster, 1988). Similarly, Jiang et al. (2000) conclude that although reasons of user resistance usually differ from system to system, uncertainty and changes in job content are common causes of user resistance. Waddell and Sohal (1988) conclude that people do not resist change per-se, rather they resist the uncertainties and potential outcomes that change can cause. Indeed, Lin (1994) finds that users in Taiwan have more tolerance towards uncertainty and human relationship is a primary catalyst during IT implementation.

Table 3 Summary of user resistance examined in three areas mentioned below

\begin{tabular}{|l|l|l|}
\hline System oriented & People oriented & Interaction oriented \\
\hline $\begin{array}{l}\text { User interface, ease of use } \\
\text { (Markus, 1983) }\end{array}$ & $\begin{array}{l}\text { Background, traits, attitudes } \\
\text { and experiences (Markus, } \\
1983)\end{array}$ & $\begin{array}{l}\text { Perceived social loss caused by } \\
\text { interaction between people and } \\
\text { technology (Markus, 1983) }\end{array}$ \\
\hline
\end{tabular}




\begin{tabular}{|c|c|c|}
\hline $\begin{array}{l}\text { System reliability and data } \\
\text { quality issues (Dickson and } \\
\text { Wetherbe, 1985; Markus, } \\
\text { 1983; Martinko, 1996; } \\
\text { Hirschheim and Newman, } \\
\text { 1988) }\end{array}$ & $\begin{array}{l}\text { Impact of internal and external } \\
\text { influences (Martinko et al. } \\
\text { 1996) }\end{array}$ & $\begin{array}{l}\text { Increased access to the data but } \\
\text { lesser autonomy (DeSanctis } \\
\text { and Courtney, 1983; Jiang et al. } \\
\text { 2000; Joshi, 1991; Krovi, } \\
\text { 1993; Lapointe and Rivard, } \\
\text { 2005, 2007; Dickson and } \\
\text { Wetherbe, 1985; Husain and } \\
\text { Husain, 1984; Joshi, 1991) }\end{array}$ \\
\hline $\begin{array}{l}\text { Ease of using a new system } \\
\text { (Dickson and Wetherbe, 1985) }\end{array}$ & $\begin{array}{l}\text { Positive } \quad \text { expectancies } \\
\text { (Bukhari, 2005; Norzaidi et al. } \\
\text { 2008) }\end{array}$ & $\begin{array}{l}\text { Psychological contract and } \\
\text { new technology (Klaus and } \\
\text { Blanton, 2010) }\end{array}$ \\
\hline $\begin{array}{l}\text { Improved task performance } \\
\text { and decision quality (Lapointe } \\
\text { and Rivard, 2005) }\end{array}$ & $\begin{array}{lrr}\text { Individual vs group } & \text { level } \\
\text { resistance } & \text { (Lapointe } & \text { and } \\
\text { Rivard, 2005) } & & \end{array}$ & $\begin{array}{l}\text { Lack of organisational fit } \\
\text { (Meissonier et al. 2012) }\end{array}$ \\
\hline $\begin{array}{l}\text { Users involvement (Ives and } \\
\text { Olsen, 1984) }\end{array}$ & $\begin{array}{l}\text { IT Skills (Markus et al. 2000; } \\
\text { Besson and Rowe, 2001; Jiang } \\
\text { et al. 2000; Krovi, 1983) }\end{array}$ & $\begin{array}{l}\text { Social influence (Eckhardt et } \\
\text { al. 2009) }\end{array}$ \\
\hline \multirow{4}{*}{$\begin{array}{l}\text { Experienced based perceptions } \\
\text { (Carney, 2002; Venkatesh and } \\
\text { Davis, 1996, 2000; Tzeng, } \\
\text { 2011) }\end{array}$} & $\begin{array}{l}\text { Changes in job content (Jiang } \\
\text { et al. 2000) }\end{array}$ & $\begin{array}{l}\text { Uncertainty (Jiang et al. 2000; } \\
\text { Waddell and Sohal, 1988) }\end{array}$ \\
\hline & $\begin{array}{l}\text { Special training programs to } \\
\text { reduce anxiety and negative } \\
\text { attitude (Henry, 1994) }\end{array}$ & \\
\hline & $\begin{array}{l}\text { Cynicism (Selander and } \\
\text { Henfridsson, 2012) }\end{array}$ & \\
\hline & $\begin{array}{l}\text { Personality factors (such as } \\
\text { age, education, needs, } \\
\text { communication, training) } \\
\text { (Fuerst and Cheney, 1982; } \\
\text { Lucas, 1973; Dickson and } \\
\text { Wetherbe, 1985; Sander and } \\
\text { Courtent, 1985). }\end{array}$ & \\
\hline
\end{tabular}




\section{Overcoming Resistance from the Users}

The issue of overcoming the resistance from the users has been a subject of several studies (Umble et al., 2003; Somers and Nelson, 2004; Kim and Kankanhalli, 2009). By using empirical studies, case studies and surveys, the authors have identified different strategies to over user resistance. Applying the change management model, the strategies can be identified into four approaches: directive, participative, supportive and coercive (Dunford et al., 1990, Shang, 2012). Directive approach refers to the use managerial authority to implement changes. Proper training (Sander and Courtent, 1985), rewarding ideas for business improvement, documentation of new processes are essence of directive approach (Umble et al., 2003, Somers and Nelson, 2004, Basoglu et al. 2007). Participative approach refers to involving people in change management process. This can performed by vision sharing (Dong et al. 2009), empowering users (Kotter and Schlesinger, 1979), involving users in system development process (Mumford, 1979), communication and feedback channel (Magal and Strouble, 1991; Chang, et.al., 2013), participation (Chang, 2013) and information sharing about new system (Liam et al. 2005). Chang et al. (2013) study the development of frameworks in the area of cloud computing, implementation and services. Using case studies to present the validity of the model, they suggest that through positive feedback and involvement from the user community and evidences of presenting deliverables could lead to overcoming the user resistance.

Waddell and Sohal (1998) suggest that participative techniques are the best method of handling resistance. Through carefully managed process of two way communication, information sharing and consultation, employees tend to become more committed to the change effort rather than a compliant to it. Similarly, Jiang et al. (2002) find participative strategies playing critical role in 
system acceptance supported with user training, orientation session and retraining employee have been observed to reduce the resistance.

Next, supportive approach concerns with moral aspect of the employee during the change process. Kim and Kankanhalli (2009) find that perceived value and organisational support for change can reduce user resistance. Other support such as employees participation and empowerment (Sagie and Koslowsky, 2000), Orientation sessions (Dong et al. 2009) and staff appreciation (Lim et al. 2005) can useful in minimising the resistance.

Davis (1989) finds that ease of use and usefulness of the system impact the level of resistance offered by the users. This is supported by Chang (2014), who by using business intelligence as a service in the cloud enabled ordinary users power to compute, visualize and analyse the risk and the prices of the stock. This empowerment enables them to make their investment decision without any IT resistance.

In contrast, coercive approach claims that forcing or imposing the change on employees is the most effective way managing resistance. It may include firing or transferring people or threatening of job promotion possibilities (Kotter and Schlesinger, 1979).

Chang and Willis (2013) study the implementation of cloud computing as education as a service model in a UK university. By adopting strategies, such as, learning by doing it, they observe $15 \%$ increases in user satisfaction with minimal resistance. They argue that in order to minimise the resistance, experienced IT personal should show user how to do it, train them with right skills which ensuring that they understand the process. This is often also called action research. Elearning could play essential role by providing staff training and executive education which in turn enhance the user acceptance. Chang (2015) find significant role played by e-learning in several organisation such as Royal Bank of Scotland, Cisco and Cap Gemini Earnst and Young. He 
identifies interactive learning as another essential tool to minimise user resistance. Interactive learning is the combination of both e-learning and face-to-face learning. It has played critical role in increasing motivation, learning interest and efficiency.

Table 4 Strategies to minimise resistance in the literature

\begin{tabular}{|l|l|}
\hline Training & Aggarwal (1998), Chang (2013, 2014, 2015) \\
\hline Establishing user support services & Rousseu (1998) \\
\hline Hands-on & $\begin{array}{l}\text { Zuboff (1988), Chang (2014), Chang and Willis } \\
\text { (2013) }\end{array}$ \\
\hline Appreciating new system usage & Klein et al. (1990) \\
\hline Encouraging communication & Jager (1994) \\
\hline Involving user in design process & $\begin{array}{l}\text { Mumford (1979, 1981, 1993), Baroudi et al. } \\
\text { (1986), }\end{array}$ \\
\hline Documenting standard for new system & Nord and Tucker (1987) \\
\hline Positive feedback and involvement & Change et al. (2013) \\
\hline Counseling & Holmes and Holmes (1970) \\
\hline User right directives & Karat (1989) \\
\hline Role modification & Klein et al. (1990) \\
\hline Interactive learning & Chang (2015) \\
\hline Ease of use and usefulness & Kavis (1989) \\
\hline
\end{tabular}




\begin{tabular}{|l|l|}
\hline Providing financial incentives & Lawler and Mohrman (1991) \\
\hline Participation & Chang (2013) \\
\hline
\end{tabular}

\section{Conclusion}

Understanding user resistance is critical to ensure successful implementation, and therefore to reap the benefits of new technology. This study shows that user resistance is a primary concerns in any new IT implementation. The literature often suggests that user resistance is a reaction to changes and uncertainty. However, as also observed in the literature, it is a far more complex phenomenon involving various players and factors demanding a comprehensive understanding of the issue. The result of this review suggests that there is not a tactic or 'silver bullet' which can avoid user resistance, rather it is a product of a variety of factors inside the organisation which contributes towards user resistance. These are uncertainty, loss of power, lack of involvement in the change process, and reluctance to change. Several strategies are proposed to overcome user resistance. These are, training, increasing user involvement, incorporating their feedback in decision making, communication and job reassignment.

User resistance offers several potential areas for future research. It is due to its pervasive nature that user resistance is focused of research originating from diverse areas such as human resources, organisational culture, to organisational behaviour. This suggests that user resistance related research should be interdisciplinary. In our opinion, research in the area of user resistance will continue to grow for the foreseeable future, since there is a continuing need for greater and better understanding of the phenomenon due to evolving nature of IT. After rigorous review of the literature, we propose the following areas for further research to enhance the understanding of user resistance: 
i. A further research on formulating the theories of user behavior and resistance in the context of new technologies such as cloud computing, enterprise system, etc.

ii. A comprehensive study to identify the factors contributing towards resistance particularly in context of current IT trends and users capabilities.

iii. A study on the user expectations and fears from introduction of new IT system to minimise user resistance.

This paper provides the reader with an overview of the user resistance in the IT field. It explores the causes of user resistance and also provides strategies how to overcome the resistance. In addition, the review could assist managers in understanding as why resistance exists and suggest strategies to adopt to overcome resistance. The review and analysis can hopefully provide a basis for further research in the areas mentioned above and will contribute towards a better understanding of user behavior in overcoming barriers to resistance.

\section{References}

Agarwal, R. \& Prasad, J. (1998). A Conceptual and operational definition of personal innovativeness in the domain of information technology. Information Systems Research, 9(2), 204215.

Argyris, C. (1970). Intervention Theory and Method, Reading, Mass., Addison-Wesley

Akkermans, H.A. \& van Helden, K. (2002). Vicious and virtuous cycles in ERP implementation: a case study of interrelations between critical success factors. European Journal of Information Systems, 11, 35-46.

Ajzen, I. (1991). The theory of planned behavior. Organisational Behaviour and Human Design Process, 50, 179-211. 
Ali, M. (2013). Decision support for ERP implementation in small and medium enterprises, PhD thesis, University of Greenwich, London, UK.

Anderson, N. H. (1974). Cognitive algebra: Integration theory applied to social attribution.

In L. Berkowitz (Ed.,), Advances in experimental social psychology, 7, l-101.

Ang, J. \& Pavri, F. (1994). A Survey and Critique of the Impacts of Information Technology, International Journal of Information Management 14(2), 122-133.

Ansoff, I. (1988). The New Corporate Strategy, John Wiley \& Sons, New York, NY.

Ansoff, I.H. (1990). Implanting strategic management, Prentice Hall, London.

Ashforth, B.E. \& Mael, F.A. (1998). The power of resistance: sustaining valued identities. Power and Influence in Organisations, Sage, London.

Atkinson, J. W. (1964). An introduction to motivation. Princeton, NJ.

Barker, T. and Frolick, M. (2003). ERP implementation failure: A case study. Journal for Service Research. 20(4). 43-49

Baroudi, J.J., Olson, M.H. \& Ives, B. (1986). An empirical study of the impact of user involvement on system usage and information satisfaction. Communication of ACM. 29(3), 232-238.

Barr, P.S., Stimpert, J.L. \& Huff, A.S. (1992). Cognitive change, strategic action and organisational renewal. Strategic Management Journal, 13, 15-36.

Beer, M. \& Eisenstat, R.A. (1996). Developing an organisation capable of implementing strategy and learning. Human Relations, 49(5), 156-166. 
Besson, P. \& Rowe, F. (2001). ERP project dynamics and enacted dialogue: perceived understanding, perceived leeway, and the nature of task-related conflicts. Database for Advances in Information Systems, 32, 47- 66.

Bhattacherjee, A. (2001). Understanding information systems continuance: an expectation confirmation model. MIS Quarterly, 25(3), 357-370.

Bingi, P., Sharma, M.K., \& Godla, J.K. (1999). Critical issues effecting an ERP implementation. Information System Management, 16(3), 7-14.

Blau, P.M. (1970). The formal theory of differentiation in organisations. American Sociological Review, 35, 201-218.

Brown, S., Massey, A., Montoya-Weiss, M. \& Burkman, J. (2002). Do I really have to? User acceptance of mandated technology. European Journal of Information Systems, 11(4), 283-295.

Bukhari, R.H. (2005). The relationship between system usage and user satisfaction: a metaanalysis. The Journal of Enterprise Information Management, 18(2), 211-234.

Chang, V., Walters, R.J. and Wills, G. (2013). The framework that leads to the cloud computing business framework. International Journal of Information Management. 33(3), 524-538

Chang, V. (2013). Brain segmentation- a case study of biomedical cloud computing for education and research. In. Learning Technologies Workshop, Higher Education Academy (HEA), University of Greenwich.

Chang, V. and Will, G. (2013). A university of Greenwich case study of cloud computing education as a service. In, E-Logistics and E-Supply Chain Management: Applications for Evolving Business, IGI Global. 
Chang, V. (2014). The business intelligence as a service in the cloud. Future Generation Computer Systems. 37, 512-524.

Chang, V. (2015). The role and effectiveness of e-learning for the industry. Lambert.

Chreim, S. (2006). Managerial frames and institutional discourses of change: employee appropriation and resistance. Organization Studies, 27(9), 1261-87.

Coetsee, L.D. (1999). From resistance to commitment. Public Administration Quarterly, 23(2), 204-222.

Conner, D.R. (1993). Managing at the speed of change: How resilient managers succeed and prosper where other fails. Random House of Canada, Toronto.

Cooper, R. \& Zmud, R. (1990). Information technology implementation research: a technological diffusion approach. Management Science, 36(2), 123-139.

Croasdell, D., Kuechler, B. \& Wawdo, S. (2013). Examining resistance to information system implementation. Journal of Information Technology Case and Application Research, 15(3), 3-24.

Cumbie, B. A., Jourdan, Z., Peachey, T., Dugo, T. \& Craighead, C.W. (2005). Enterprise Resource Planning Research: Where Are We Now and Where Should We Go from Here?. Journal of Information Technology Theory and Application, 7(2), 21-36.

Davenport, T.H. (1998). Putting the enterprise into the enterprise systems. Harvard Business Review, 76(4), 121-131.

Davis, F.D. (1989). Perceived usefulness, perceived ease of use, and user acceptance of information technology. MIS Quarterly, 13(3), 319-340. 
Davis, F.D., Bagozzi, R.P. \& Warshaw, P.R. (1989). User acceptance of computer technology: a comparison of two theoretical models. Management Science, 35(8), 982-1003.

Davidson, J.O.C. (1994). The source and limits of resistance in a privatized utility. Resistance and power in an organisation. Routledge, London.

De Jager, P. (1994). Communication in the time of change. Journal of System Management, 45(6), 28-30.

DeSanctis, G., \& Courtney, J. F. (1983).Toward Friendly User MIS Implementation. Communications of the ACM. 26(10), 732-738.

Dickson, G. \& Simmons, J. (1970). The behavioural side of MIS: some aspects of the 'People Problem’. Business Horizon.

Dickson, G.W. \& Wetherbe, J. (1985). The Management of Information Systems, McGraw-Hill, New York.

Doolin, B. (2004). Power and resistance in the implementation of a medical management information system. Information Systems Journal, 14(4), 343-362.

Doppler, K. (2004). Managing Change successfully: core questions, issues, and strategies. Dynamics of Organisational Change and Learning, John Wiley \& Sons, UK.

Eckhardt, A., Laumer, S. \& Weitzel, T. (2009). Who influences whom? Analysing workplace referents' social influence on IT adoption and non-adoption. Journal of Information Technology, $24,11-24$.

Eveland, J. (1977). Implementation of innovation in organsiation: a process approach. Ph.D. thesis, University of Michigan. 
Finney, S. \& Corbett, M. (2007). ERP implementation: a compilation and analysis of critical success factors. Business Process Management. 13(3), 329-347.

Fishbein, M. \& Ajzen, I. (1975). Belief, Attitude, Intention and Behavior: An Introduction to Theory and Research, Addison-Wesley, Reading, MA.

Fiorelli, J.S. \& Margolis, H. (1993). Managing and understanding large systems change: guidelines for executives and change agents. Organisation Development Journal, 11(3), 1-13.

Fleishman, E. A. (1958). A relationship between incentive motivation and ability level in psychomotor performance. Journal of Experimental Psychology, 56, 78-81.

Fried, L. (1972). Hostility in organsiation change. Journal of Systems Management. 6.

Furest, W.L. \& Cheney, P.H. (1982). Factors affecting the percent of utilization of computer based decision support system in the oil industry. Decision Sciences, 13, 148-165.

Gabriel, Y. (1999). Beyond happy families: a critical reevaluation of the control-resistance-identity triangle. Human Relations, 52, 179-203.

Ginzberg, E. \& Reilley, E. (1957). Effecting changes in large organisations, Columbia University Press, New York.

Goodhue, D.L. \& Thompson, R. L. (1995). Task-technology fit and individual performance. MIS Quarterly, 19(2), 213-236.

Gravenhorst, K.B. \& Veld, R. (2004). Power and collaboration: methodologies for working together in change. Dynamics of Organisational Change and Learning, John Wiley \& Sons, UK.

Griffiths, M. \& Light, B. (2009). An investigation into resistance practice at an SME consultancy. Journal of Enterprise Information Management, 22 (1/2), 119-136. 
Grusky, O. \& Miller, G. (1970). The Sociology of Organisations, Free Press, New York, NY.

Hannan, M. \& Freeman, J. (1984). Structural inertia and organisational change, American Sociological Review, 49, 149-164.

Hanson, J. (2001). Implementation of TQM in Small Organisation, experience from award winners in Sweden, Licentiate Thesis 2001, Lulea University of Technology.

Hartmann, T., Fischer, M. \& Haymaker, J. (2009). Implementing information systems with project teams using ethnographic-action research. Advanced Engineering Informatics, 23(1), 57-67.

Heany, D. (1972). Education: the critical link in getting managers to use management systems. Interface, 2(3).

Henry, J.W. (1994). Resistance to computer based technology in the work place. Executive Development, 7(1), 20-23.

Heider, F. (1944). Social perception and phenomenal casuality. Psychological Review, 51, 358-374.

Hill, K. (2003). System designs that start at the end (user), CRM Daily.

Hirschhiem, R. \& Newman, M. (1988). Information systems and Users resistance: theory and practice. The Computer Journal, 31(5), 398-408.

Hjelt, M., \& Bjork, Bo-Christer. (2006). Experiences of EDM Usage in Construction Projects. ITcon, 11, 113-125.

Holland, C.P. \& Light, B. (1999). Global enterprise planning implementation, in: $32^{\text {nd }}$ International Hawaii Conference: HICSS’99, Big Island, Hawaii, 1999. 
Holmes, T.S. \& Holmes, T.H. (1970). Short-term intrusions into lifestyle routines. Journal of Psychosomatic Research, 14, 121 - 132.

Hong, W., Wong, W., Thong, J., \& Tam, K. (2002). Determinants of user acceptance of digital libraries: an empirical examination of individual differences and system characteristics. Journal of Management Information Systems, 18(3), 97-124.

Huber, G. (1983). Cognitive style as the basis for MIS and DSS designs: much ado about nothing?. Management Science, 29(5), 567-577.

Husain \& Husain (1984). Information Resource Management. Irwind Homedwood IL.

Ives, B. \& Olson, M. (1984). User involvement and MIS success: a review of research. Management Science, 30(5), 586-603.

Jain, A. (2004). Using the lens of Max Weber's theory of bureaucracy to examine e-government research, paper presented at $37^{\text {th }}$ Hawaii International Conference on System Science, Hawaii.

Jiang, J.J., Muhanna, W.A. \& Klein, G. (2000). User resistance and strategies for promoting acceptance across systems types. Information Management, 37, 25-36.

Joseph, R.C. (2010). Individual resistance to IT innovation.Communications of the ACM, 53(4), 144-146.

Joshi, K. (1991). A model of Users' perspective on change: the case of information system technology implementation. MIS Quarterly, 15(2), 229-242.

Joshi, K. (2005). Understanding users resistance and acceptance during the implementation of an order management system: a case study using the equity implementation model. Journal of Information Technology Case and Application Research, 7(1), 6-20. 
Judson, A. (1966). A Managers Guide to Making Changes, John Wiley \& Sons, London.

Karahanna, E., Straub, D.W. \& Chervany, N.L. (1999). Information technology adoption across time: A cross sectional comparison of pre-adoption and post-adoption beliefs. MIS Quarterly.23

92), 183-213

Karat, C.M. (1998).Guaranteeing rights for the user. Communications of the ACM, 41(12) 29 - 31.

Kaufman, H. (1971). The Limits of Organisational Change, University of Alabama Press,

Tuscaloosa, AL.

Kim, H.W. (2011). The effect of switching costs on user resistance to enterprise system implementation. IEEE Transactions on Enterprise system implementation, 58(3), 471-483.

Kim, Y., Lee, Z. \& Gosain, S. (2005). Impediments to successful ERP implementation process. Business Process Management Journal, 11(2), 158-170.

Kim, H.W. \& Kankanhalli, A. (2009).Investigating user resistance to information system implementation: status quo bias perspective. MIS Quarterly, 33, 567-582.

Kim, H.W. and Pan, S.L. (2006). Towards a process model of information systems implementation: The case of customer relationship management. Database Advanced Information System. 37(1). 59-76

Klaus T. \& Blanton, J.E. (2010). User resistance determinants and the psychological contract in enterprise system implementations. European Journal of Information Systems, 19, 625-636.

Klein, K.J. \& Sorra, J. S. (1996). The challenge of innovation implementation. Academy of Management Review, 21(4), 22-42. 
Klein, K.J., Hall, R.J. \& Laliberte, M. (1990). Training and the organizational consequences of technological change: a case study of computer-aided design and drafting, in: U.E. Gattiker, L. Larwood (Eds.), Technological Innovation and Human Resources: End-User Training, de Gruyter, New York, 7 -36.

Kling, R. (1980). Social analyses of computing: Theoretical perspective in recent empirical research. Comput. Serv., 12(1), 61-110.

Kotter, J. P. (1996). Leading change: Why transformation efforts fail. Harvard Business Review, 73, 59-67.

Kotter, J. Schlesinger, L. \& Sathe, V. (1986). Organisation, 2nd ed, Irwin, Homewood, IL.

Krovi, R. (1993). Identifying the causes of resistance to IS implementation. Information \& Management, 25(4), 327-335.

Kruger, W. (1996). Implementation: the core task of change management, CEMS Business Review, 1, 77-96.

Kuhl, J. (1985). Volitional aspect of achievement motivation and learned helplessness:

Toward a comprehensive theory of action control. In B. A. Maher (Ed.), Progress in experimental personality research, 13, . 99-171). New York: Academic Press.

Lapointe, L. and Rivard, S. (2000). A multilevel model of resistance to information technology implementation. MIS Quarterly, 29(3), 461-491.

Lawler, E. \& Mohrman, S.A. (1991). Quality circles: after the honeymoon, in: B.M. Staw (Ed.), Psychological Dimensions of Organizational Behavior, Macmillan, New York 
Lawrence, P.R. (1954). How to deal with resistance to change, Harvard Business Review, May/June, 49-57.

Lawrence, P. (1968). How to deal with resistance to change, Harvard Business Review, Jan - Feb, 47(1), 4-6

Leigh, A. (1988). Effective Change, Institute of Personnel Management, London.

Lewin, K., Dembo, T. Festiger, L. \& Sears, P.S. (1944). Level of aspiration. Personality and Behaviour Disorder, 1, 333-378.

Lin, T. (1994). An integrated model for users resistance to information systems: The Taiwan case. Journal for Information Technology Management, 5(3), 47-58.

Lines, R. (2004). Influence of participation in strategic change: resistance, organizational commitment, and change goal achievement. Journal of Change Management, 4(3), 193-215.

Liska, A. E. (1984). A critical examination of the causal structure of the Fishbein/Ajzen attitude-behavior model. Social Psychology Quarterly, 47, 61-74.

Locke, E. A. (1965). Interaction of ability and motivation in performance. Perceptual and Motor Skills, 21, 719-725.

Lucas, H. (1973). User reaction and management of information services. Management Informatics, 2(4).

Lycke, L. (2000). Implementing total productive maintenance, driving forces and obstacles, Thesis 2000, 15 Lulea University, Lulea.

Magal, S.R. \& Strouble, D.D. (1991). A user’s perspective of the critical success factors applicable to information center. Information Resources Management Journal, Spring, 22-34. 
Maraks, G.M. \& Hornick, S. (1996). 'Passive resistance misuse” overt support and covert recalcitrance in IS implementation. European Journal of Information System, 5(3), 208-219.

Markus, M. L. (1983). Power, politics and MIS implementation. Communication of ACM., 26(6), 430-444.

Markus, M.L., Axline, S., Petrie, D. \& Tanis, C. (2000). Learning from adopters' experience with ERP: Problems encountered and success achieved. Journal of Information Technology, 15, 245265.

Martinko, M.J., Henry, J.W. \& Zmud, R.W. (1996). An attributional explanation of individual resistance to the introduction of information technologies in the workplace. Behaviour and Information Technology, 15(5), 313-330.

Mason, R. \& Mitroff, I. (1973). A program for research on management information systems. Management Science, 19(5), 475-487.

Maurer, R. (1996). Using resistance to build support for change. The Journal of Quality and Participation, 19(3), 56-66.

McNurry, R. (1973). The Problem of Resistance to Change in Industry, Changing Organisational Behaviour, Prentice Hall, Englewood Cliffs, NJ.

Meissonier, R., \&Houze, E. (2010). Toward an /IT Conflict-Resistance Theory/': action research during IT pre-implementation. European Journal of Information Systems, 19(5): 540-561.

Meissonier, R., \& Houze, E. and Bessiere, V. (2013). Cross-cultural friction in information systems management: Research perspectives on ERP implementation misfits in Thailand, International Business Research, 6(2), 150-159. 
Morrison, E.W. \& Milliken, F.J. (2000). Organisational silence: a barrier to change and development in a pluralistic world, Academy of Management Review, 25(4), 706-725.

Mumford, E. \& Weir, M. (1979). Computer systems in work design: The ethics method, Halstead, Wiley, NY.

Mumford, E. \& Banks, O. (1967). The computer and the clerk. Routledge\&Kegan Paul, Henley.

Nah, F.F-H., Zuckweiler, K.M. \& Lau, J.L.S (2003). ERP implementation: Chief information officers' perspective of critical Success factors. International Journal of Human-Computer Interaction, 16(1), 5-22.

Nah, F.F., Tan, X. \& Teh, S.H. (2004). An empirical investigation on end-users' acceptance of enterprise systems. Information Resources Management Journal, 17 (3), 32-53.

Nemeth, C.J. (1997). Managing innovation: when less is more. California Management Review, 40(1), 59-74.

Newman, M. (1988). Folklore in ISD: some counter evidence', the Second Joint International Symposium on Information Systems, Sydney, 87-106.

Nodeson, S., Beleya, P., Raman, G. \& Ramendran, C. (2012). Leadership role in handling employees resistance: Implementation of innovation, Interdisciplinary. Journal of Contemporary Research in Business, 4(3), 466-477.

Nord, W. R. \& Tucker, S. (1987). Implementing routine and radical innovations, Lexington Books. Norzaidi, M.D. \& Salwani, M. (2007). TECHRPOVED model: a new a new invention of information technology (IT) diagnostic tool', paper presented at Invention and New products (INPEX), Pittsburgh, PA. 
Norzaidi, M. D., Chong, S.C., Salwani, M. \& Rafidah.K. (2008). A study of intranet usage and resistance in Malaysia’s port industry. Journal of Computer Information Systems,

Nov, O. \& Ye, C. (2008). Personality and technology acceptance: Personal innovativeness in IT, openness and resistance to change, Waikoloa, HI.

Oreg, S. (2006). Personality, context, and resistance to organizational change. European Journal of Work and Organizational Psychology, 15(1), 73-101.

Oserman, P. (2000). Work reorganization in an era of restructuring: trend in diffusion and effects on employee welfare. Industrial and Labour Relation Review, 53, 179-198.

Parasuraman, A. \& Grewal, D. (2000). Serving Customers and Consumers Effectively in the Twenty-First Century: Emerging Issues and Solutions. Journal of the Academy of Marketing Science 28 (Winter): 9-16.

Pieterse, J.H., Caniels, M.C.J. \& Homan, T. (2012). Professional discourse and resistance to change. Journal of Organisational Change Management, 25(6), 798-818.

Reichers, A.E., Wanous, J.P. \& Austin, J.P. (1997). Understanding and managing cynicism about organisational change. Academy of Management Executive, 11(1), 48-59.

Rivard, S. \& Lapointe, L. (2012). Information technology implementers’ response to user resistance, MIS Quarterly, 36(3), 897-920.

Rogers, E.M. (1995). Diffusion of Innovation. $5^{\mathrm{TH}}$ edition. Simon\& Schuster International.

Rosseau, D.M. (1998). The 'problems' of the psychological contract considered. Journal of Organisational Behaviour, 19(1), 665-671. 
Rumlet, R.P. (1995). Inertia and transformation, in Montgomery, C.A.(Ed.), Resource-based, and Evolutionary theories of firm, Kluwer Academic Publisher, MA, 101-32.

Sacks, C., Bellisimo, Y. \& Mergendoller, J. (1993). Attitudes toward computers and computer use: the issue of gender. Journal of Research on Computing Education , 26, 257-269.

Samuelson, W. \& Zeckhauser, R. (1988). Status quo bias in decision making. Journal of Risk and Uncertainty, 1, 7-59.

Sander, G.L. \& Courtent, J.F. (1985). A field study of organisation factors including DSS factors. MIS Quarterly, 9(1), 77-89.

Sanders, D.H. (1974). Computers and Management: In a Changing Society, 2nd Edition, McGrawHill, New York.

Sarver, V. T., Jr. (1983). Ajzen and Fishbein’s “theory of reasoned action”: A critical assessment. Journal for the Theory of Social Behavior, 13, 155-163.

Sayles, L. and Straus, G. (1960). Human Behaviour in Organisations, Prentice Hall, London.

Schalk, R., Campbell, J.W. \& Freese, C. (1998). Change and employee relation behaviour. Leadership and Organisational Development Journal, 19(3), 157-163.

Schein, E. (1988). Organisational Psychology, $3^{\text {rd }}$ edition. Prentice Hall, Englewood Cliffs, NJ.

Schepers, J. \& Wetzels, M. (2007).A meta-analysis of the technology acceptance model: investigating subjective norm and moderation effects. Information and

Management, 44(1), 90-103.

Selander, L. \& Henfridsson, O. (2012). Cynicism as a user resistance in IT implementation. Info System Journal, 22, 289-312. 
Shang, S.C. (2012). Dual strategy for managing user resistance with business integration systems. Behaviour and Information Technology, 31(9), 909-925.

Soja P. (2006). Success factors in ERP systems implementation; lesson learnt from practice. Journal of Enterprise Information Management, 19(4), 418-433.

Starbuck, W., Greve, A., \& Hedberg, B.L.T. (1978). Responding to crisis. Journal of Business Administration, 9(2), 111-137.

Stanley, D.J., Meyer, J.P. \& Topolnytsky, L. (2005). Employee cynicism and resistance to organizational change. Journal of Business and Psychology, 19, 429-459.

Strebl, P. (1994). Why do employees resist change, Harvard Business Review, 86-92.

Tetlock, P.E. (2000). Cognitive biases and organizational correctives: do both disease and cure depend on the politics of the beholder?. Administrative Science Quarterly 45(2), 293-326.

Thompson, R.L., Higgins, C.A. \& Howell, J.M. (1991). Personal computing toward a conceptual model of utilization. MIS Quarterly,15(1), 125-43.

Triandis, H. C. (1977). Interpersonal behavior. Monterey, CA.

Tzeng, J. (2011). Perceived values and prospective users' acceptance prospective technology: The case of career eportfolio system. Computer and Education, 56(1), 157-165.

Umble, E.J. \& Umble, M.M. (2002). Avoiding ERP implementation Failure. Industrial Management, 44(1), 25-33.

Val, M.P. \& Fuentes C.M. (2003). Resistance to change: a literature review and empirical study, Management Decision, 41(2), 148-155. 
Venkatesh, V. (2000). Determinants of perceived ease of use: Integrating control, intrinsic motivation, and emotion into the technology acceptance model. Information Systems Research, 11(4), 342-365.

Venkatesh, V. \& Bala, H. (2008). Technology acceptance model and a research agenda on intervention”, Decision Sciences, 39(2), 273-311.

Venkatesh, V., Morris, M.G. \& Davis, F.D. (2003). User acceptance of information

technology: toward a unified view. MIS Quarterly, 27(3), 425-78.

Venkatesh, V. \& F. D. Davis (1996). A model of the antecedents of perceived ease of use: Development and test. Decision Science, 27, 451-481.

Verton, D. (2002). Insiders slam navy intranet, the massive NMCI intranet project is under fire from navy insiders. Computer World. [Online].Available: http://www.computerworld.com/managementtopics/management/outsourcing/story/0108017147 1,00.html

Vroom, V. H. (1964). Work and motivation. New York: Wiley.

Waddell, D. \& Sohal, A.S. (1998). Resistance: a constructive tool for change management. Management Decision, 36(8), 543-548.

Wanberg, C. \& Banas, J. (2000). Predictors and outcomes of openness to changes in a reorganizing workplace. Journal of Applied Psychology, 85(1),132-42.

Weston, F.C. (2001). ERP implementation and project management. Production and Inventory Management Journal, 42, 75-80. 
Willcocks, L.P. \& Sykes, R. (2000). The role of the CIO and IT function in ERP. Communication of the ACM, 43, 32-38.

Yang, Z. \& Peterson, R. (2004). Customer Perceived Value, Satisfaction, and Loyalty: The Role of Switching Costs. Psychology\& Marketing, 21(10), 799-822.

Zaltman, G. \& Duncan, R. (1977).Strategies for planned change, Wiley, Toronto.

Zhang, Z., Lee, M.O., Huang, P., Zhang, L. \& Huang, X. (2005). A framework of ERP systems implementation success in China; an empirical study. International Journal of Production Economics, 98(1), 56-80.

Zmud, R.W. (1979). Individual differences and MIS success: A review of the empirical literature. Management Science, 25(10).

Zeffane, R. (1996). Dynamics of strategic change: critical issues in fostering organisational change. Leadership and Organisation Development Journal, 17(7), 36-43.

Zuboff, S. (1988). In the Age of the Smart Machine: The Future of Work and Power, Basic Books: New York. 